\title{
Effectiveness of Dupilumab for an Elderly Patient with Prurigo Nodularis Who Was Refractory and Contradicted to Traditional Therapy
}

This article was published in the following Dove Press journal:

Journal of Asthma and Allergy

\section{Taoming Liu \\ Juan Bai \\ Su Wang \\ Shuni Ying \\ Sheng $\mathrm{Li}$ (D) \\ Jianjun Qiao (D) \\ Hong Fang}

Department of Dermatology, The First Affiliated Hospital, Zhejiang University School of Medicine, Hangzhou, People's Republic of China
Correspondence: Jianjun Qiao; Hong Fang Department of Dermatology, The First Affiliated Hospital, Zhejiang University School of Medicine, No. 79 Qingchun Road, Hangzhou, People's Republic of China

Tel/Fax+86-57I-87236706

Email qiaojianjun@zju.edu.cn;

fanghongzy@zju.edu.cn

\begin{abstract}
Prurigo nodularis $(\mathrm{PN})$ is an intense pruritic skin condition. Treatment of $\mathrm{PN}$ is challenging. We described an elderly patient with PN who had contradictions of cyclosporine or methotrexate and achieved significant improvement after treatment with dupilumab. We also reviewed published cases of elderly patients with PN who were refractory to traditional therapy.
\end{abstract}

Keywords: prurigo nodularis, dupilumab, elderly patient, targeted therapy

\section{Introduction}

Prurigo nodularis (PN) is a chronic inflammatory skin disease, which is characterized by intractable pruritus and hyperkeratotic nodules. Effective treating options for PN are limited. Systemic therapies (methotrexate, cyclosporine, and thalidomide) are burdened by a high incidence of serious adverse effects, especially in elderly patients. ${ }^{1}$ Dupilumab is a fully humanized interleukin (IL)-4R $\alpha$ antibody. It has been demonstrated to be effective and safe for treating patients with PN with or without atopic history. ${ }^{2}$ Herein we reported a case of elderly patient with refractory $\mathrm{PN}$, and effectively treated with dupilumab.

\section{Case Presentation}

An 85-year-old man presented with a 16-year history of PN. He had a history of interstitial lung disease and denied to have atopic background. Physical examination revealed widespread erythematous nodules, plaques, papules, and excoriations on the scalp, extremities, and trunk (Figure 1). Blood tests showed an eosinophil count $0.53 \times 10^{9} / \mathrm{L}$ (normal range $0.02-0.50 \times 10^{9} / \mathrm{L}$ ), total $\operatorname{IgE}$ level $242 \mathrm{KU} / \mathrm{L}$ (normal range $<100.0 \mathrm{KU} / \mathrm{L}$ ), and a glomerular filtration rate $37 \mathrm{~mL} / \mathrm{min}$. This study procedure was given ethical approved by the ethics committees of The First Affiliated Hospital, Zhejiang University School of Medicine (Approved number: IIT20210020A). The patient has given the written informed consent to this case report with all details displayed and the corresponding images.

In the past one month, he had been administrated with gabapentin 300mg twice daily, thalidomide 50mg daily, ketotifen $1 \mathrm{mg}$ per night, NB-UVB twice weekly, and topically halomethane cream as needed. However, these treatments failed to relieve his pruritus. Therefore, the patient was transferred from a local hospital to our department. Due to the low glomerular filtration rate $(37 \mathrm{~mL} / \mathrm{min})$ and interstitial lung disease 

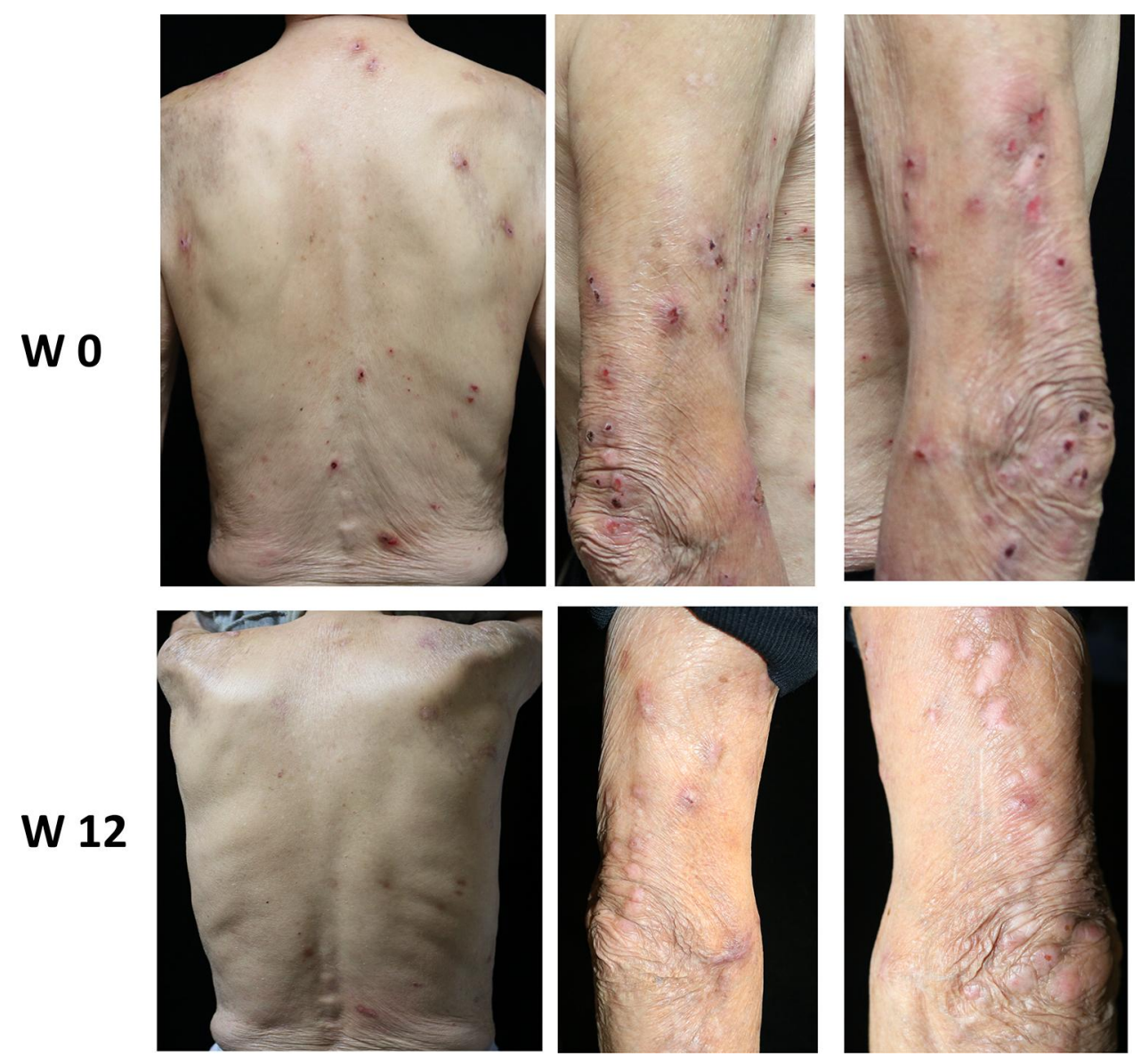

Figure I Clinical presentation of an elderly patient with prurigo nodularis. Prurigo nodularis lesions involving the upper limbs and the trunk at baseline (W0). They were improved after dupilumab therapy at week 12 (WI2).

history, cyclosporine and methotrexate were not recommended to the elderly patient. As suffering from intensive pruritus and low quality of life, this patient was treated with dupilumab with standard doses of $600 \mathrm{mg}$ subcutaneously at week 0 and then $300 \mathrm{mg}$ every other week. During the first 8 -week treatment, the patient was continuing to receive cetirizine $10 \mathrm{mg}$ per day, ketotifen $1 \mathrm{mg}$ per night, and topically halomethane cream as needed. Within 12 weeks, the patient gradually achieved improvement of itch intensity measured by visual analogue scale. In order to evaluate the change of cutaneous lesions, we used the tools of investigator's global assessment and prurigo activity score. The later one represents the patient's overall disease severity measured by counted number of nodules at the same represented location. $^{3}$ During the 12-week therapy with dupilumab, reductions were observed in disease severity as assessed on
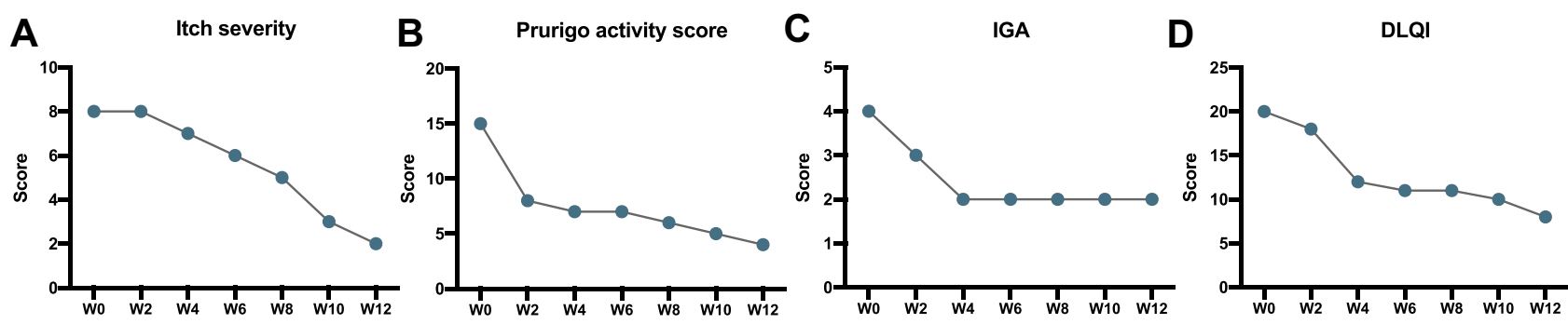

Figure 2 Clinical scores of an elderly patient with prurigo nodularis during dupilumab therapy. (A) The changes of itch severity were measured by visual analogue scale. The changes of cutaneous lesions were assessed by (B) the counted number of nodules in dorsal side of the trunk and (C) IGA. (D) The quality of life was tested by DLQI. Abbreviations: IGA, investigator's global assessment; DLQI, Dermatology Life Quality Index. 
the itch score, prurigo activity score (location: the dorsal site of the trunk), investigator's global assessment, and Dermatology Life of Quality of Index (Figure 2). No adverse effects were reported during the therapy.

\section{Discussion}

It has been identified that the levels of IL-4, IL-13, and IL-31 are increased in lesions of patients with PN. ${ }^{4,5}$ Dupilumab inhibits $\mathrm{T}$ helper 2 immune response by blocking IL-4 and IL-13 pathway. ${ }^{6}$ Dupilumab is likely to break the itchscratch cycle of PN through inhibiting these cytokines.
Case series and case reports recently have showed the satisfied efficacy and safety of dupilumab for the treatment of elderly patients with PN (Table 1), ${ }^{7-11}$ particularly those failed to traditional therapy. Our case report contributes to the increasing evidence that dupilumab is a therapeutic choice for elderly patients with PN contradicted to traditional therapy.

\section{Conclusion}

In summary, our case report further suggests that dupilumab could be considered as a potential and well-tolerated

Table I Review of Cases of Elderly Patients with Prurigo Nodularis Treated by Dupilumab

\begin{tabular}{|c|c|c|c|c|c|c|c|}
\hline References & Age & Gender & $\begin{array}{l}\text { History } \\
\text { of Atopic } \\
\text { Diseases }\end{array}$ & Blood Tests & $\begin{array}{l}\text { Treatment Failures Before } \\
\text { Dupilumab Therapy }\end{array}$ & $\begin{array}{l}\text { Effected Evaluation of } \\
\text { Dupilumab Therapy }\end{array}$ & $\begin{array}{l}\text { Adverse } \\
\text { Events }\end{array}$ \\
\hline Beck et $\mathrm{al}^{7}$ & $70 \mathrm{~s}$ & Male & NA & NA & $\begin{array}{l}\text { Corticosteroids, hydroxyzine } \\
\text { hydrochloride, doxepin, dronabinol, } \\
\text { gabapentin, phototherapy, } \\
\text { cryotherapy, }\end{array}$ & $\begin{array}{l}\text { Pruritus and skin lesions } \\
\text { improved with in } 8 \text { weeks }\end{array}$ & No \\
\hline Giura et $\mathrm{al}^{8}$ & 85 & Female & NA & $\begin{array}{l}\text { Total lgE I68 } \\
\mathrm{KU} / \mathrm{L}, \mathrm{LDH} \\
555 \mathrm{UI} / \mathrm{L} \\
\text { eosinophil } \\
\text { count } \\
0.98 \times 10^{9} / \mathrm{L}\end{array}$ & $\begin{array}{l}\text { Topical and systemic } \\
\text { corticosteroids }\end{array}$ & $\begin{array}{l}\text { Pruritus and skin lesions } \\
\text { approximately } \\
\text { disappeared }\end{array}$ & No \\
\hline $\begin{array}{l}\text { Kovács } \\
\text { et al }\end{array}$ & 80 & Female & $\begin{array}{l}\text { Atopic } \\
\text { dermatitis }\end{array}$ & High total IgE & $\begin{array}{l}\text { Topical corticosteroids, topical } \\
\text { calcineurin inhibitors, } \\
\text { antihistamines, antidepressants, } \\
\text { gabapentin, cyclosporine, } \\
\text { methotrexate, naloxone, UVB } \\
\text { irradiation, }\end{array}$ & $\begin{array}{l}\text { Pruritus improved with in } \\
10 \text { weeks }\end{array}$ & NA \\
\hline $\begin{array}{l}\text { Criado } \\
\text { et } \text { al }^{10}\end{array}$ & 87 & Male & $\begin{array}{l}\text { Atopic } \\
\text { dermatitis, } \\
\text { rhinitis }\end{array}$ & $\begin{array}{l}\text { Elevated } \\
\text { eosinophil and } \\
\text { lgE }\end{array}$ & $\begin{array}{l}\text { Topical, intralesional, and systemic } \\
\text { corticosteroids, mirtazapine, } \\
\text { pregabalin, hydroxyzine, } \\
\text { methotrexate, cyclosporine. }\end{array}$ & $\begin{array}{l}\text { Pruritus improved with in } \\
4 \text { weeks. Pruritus and skin } \\
\text { lesions approximately } \\
\text { disappeared within } 16 \\
\text { weeks }\end{array}$ & No \\
\hline $\begin{array}{l}\text { Wieser } \\
\text { et al }{ }^{\prime \prime}\end{array}$ & 66 & Female & No & NA & $\begin{array}{l}\text { Topical corticosteroids, } \\
\text { antihistamines, prednisone, } \\
\text { methotrexate }\end{array}$ & $\begin{array}{l}\text { Pruritus improved with in } \\
20 \text { weeks, skin lesions } \\
\text { improved with in } 16 \\
\text { weeks }\end{array}$ & No \\
\hline $\begin{array}{l}\text { Wieser } \\
\text { et al }{ }^{\prime \prime}\end{array}$ & 65 & Male & No & NA & $\begin{array}{l}\text { Thalidomide, intralesional } \\
\text { triamcinolone, gabapentin, } \\
\text { phototherapy }\end{array}$ & $\begin{array}{l}\text { Pruritus and skin lesions } \\
\text { improved with in } 4 \text { weeks }\end{array}$ & No \\
\hline $\begin{array}{l}\text { Wieser } \\
\text { et al }{ }^{\prime \prime}\end{array}$ & 65 & Female & No & NA & $\begin{array}{l}\text { Topical corticosteroids, tacrolimus } \\
0.1 \% \text { ointment, antihistamines, } \\
\text { gabapentin, hydroxyzine }\end{array}$ & $\begin{array}{l}\text { Pruritus and skin lesions } \\
\text { improved with in } 28 \\
\text { weeks }\end{array}$ & No \\
\hline
\end{tabular}


treatment option for elderly patients with PN, especially in who were refractory or contradicted to conventional therapy.

\section{Acknowledgments}

This work was supported by the National Natural Science Foundation of China (81972931 to HF), and the Medical and Health Science and Technology Project of Health Commission of Zhejiang Province (2020KY558 to JQ).

\section{Disclosure}

The authors declare no conflicts of interest related to this work.

\section{References}

1. Huang AH, Canner JK, Kang S, Kwatra SG. Analysis of real-world treatment patterns in patients with prurigo nodularis. $\mathrm{J} \mathrm{Am} \mathrm{Acad}$ Dermatol. 2020;82(1):34-36. doi:10.1016/j.jaad.2019.09.007

2. Williams KA, Huang AH, Belzberg M, Kwatra SG. Prurigo nodularis: pathogenesis and management. J Am Acad Dermatol. 2020;83 (6):1567-1575. doi:10.1016/j.jaad.2020.04.182

3. Ständer S, Yosipovitch G, Legat FJ, et al. Trial of nemolizumab in moderate-to-severe prurigo nodularis. $N$ Engl J Med. 2020;382 (8):706-716. doi:10.1056/NEJMoa1908316
4. Park K, Mori T, Nakamura M, Tokura Y. Increased expression of mRNAs for IL-4, IL-17, IL-22 and IL-31 in skin lesions of subacute and chronic forms of prurigo. Eur J Dermatol. 2011;21(1):135-136. doi:10.1684/ejd.2010.1196

5. Zhong W, Wu X, Zhang W, et al. Aberrant expression of histamine-independent pruritogenic mediators in keratinocytes may be involved in the pathogenesis of prurigo nodularis. Acta Derm Venereol. 2019;99(6):579-586. doi:10.2340/00015555-3150

6. Beck LA, Thaçi D, Hamilton JD, et al. Dupilumab treatment in adults with moderate-to-severe atopic dermatitis. $N$ Engl J Med. 2014;371 (2):130-139. doi:10.1056/NEJMoa1314768

7. Beck KM, Yang EJ, Sekhon S, Bhutani T, Liao W. Dupilumab treatment for generalized prurigo nodularis. JAMA Dermatol. 2019;155(1):118-120. doi:10.1001/jamadermatol.2018.3912

8. Giura MT, Viola R, Fierro MT, Ribero S, Ortoncelli M. Efficacy of dupilumab in prurigo nodularis in elderly patient. Dermatol Ther. 2020;33(1):e13201. doi:10.1111/dth.13201

9. Kovács B, Rose E, Kuznik N, et al. Dupilumab for treatment-refractory prurigo nodularis. $J$ Dtsch Dermatol Ges. 2020;18(6):618-624. doi:10.1111/ddg.14107

10. Criado PR, Pincelli TP, Criado RFJ. Dupilumab as a useful treatment option for prurigo nodularis in an elderly patient with atopic diathesis. Int J Dermatol. 2020;59(10):e358-e361. doi:10.1111/ ijd.14994

11. Wieser JK, Mercurio MG, Somers K. Resolution of treatment-refractory prurigo nodularis with dupilumab: a case series. Cureus. 2020;12(6):e8737. doi:10.7759/cureus. 8737

\section{Publish your work in this journal}

The Journal of Asthma and Allergy is an international, peer-reviewed open-access journal publishing original research, reports, editorials and commentaries on the following topics: Asthma; Pulmonary physiology; Asthma related clinical health; Clinical immunology and the immunological basis of disease; Pharmacological interventions and new therapies. The manuscript management system is completely online and includes a very quick and fair peer-review system, which is all easy to use. Visit http://www.dovepress.com/testimonials.php to read real quotes from published authors. 